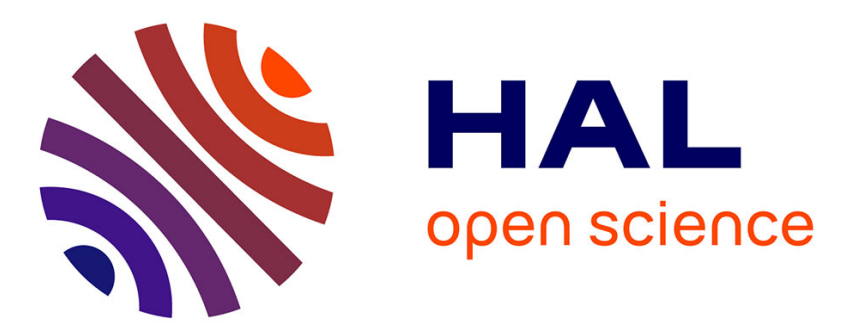

\title{
Dust transport over Iraq and northwest Iran associated with winter Shamal: A case study
}

Farhad Abdi-Vishkaee, Cyrille Flamant, Juan Cuesta, Larry Oolman, Pierre H. Flamant, Hamid R. Khalesifard

\section{- To cite this version:}

Farhad Abdi-Vishkaee, Cyrille Flamant, Juan Cuesta, Larry Oolman, Pierre H. Flamant, et al.. Dust transport over Iraq and northwest Iran associated with winter Shamal: A case study. Journal of Geophysical Research: Atmospheres, 2012, 117 (D3), pp.D03201. 10.1029/2011JD016339 . hal00660312

\section{HAL Id: hal-00660312 \\ https://hal.science/hal-00660312}

Submitted on 11 Mar 2016

HAL is a multi-disciplinary open access archive for the deposit and dissemination of scientific research documents, whether they are published or not. The documents may come from teaching and research institutions in France or abroad, or from public or private research centers.
L'archive ouverte pluridisciplinaire HAL, est destinée au dépôt et à la diffusion de documents scientifiques de niveau recherche, publiés ou non, émanant des établissements d'enseignement et de recherche français ou étrangers, des laboratoires publics ou privés. 


\title{
Dust transport over Iraq and northwest Iran associated with winter Shamal: A case study
}

\author{
Farhad Abdi Vishkaee, ${ }^{1,2}$ Cyrille Flamant, ${ }^{3}$ Juan Cuesta, ${ }^{4}$ Larry Oolman, ${ }^{5}$ Pierre Flamant, ${ }^{1}$ \\ and Hamid R. Khalesifard ${ }^{2}$ \\ Received 1 June 2011; revised 7 December 2011; accepted 10 December 2011; published 1 February 2012.
}

[1] Dynamical processes leading to dust emission over Syria and Iraq, in response to a strong winter Shamal event as well as the subsequent transport of dust over Iraq and northwest Iran, are analyzed on the basis of a case study (22-23 February 2010) using a suite of ground-based and spaceborne remote sensing platforms together with modeling tools. Surface measurements on 22 February show a sharp reduction in horizontal visibility over Iraq occurring shortly after the passage of a cold front (behind which the northwesterly Shamal winds were blowing) and that visibilities could be as low as $1 \mathrm{~km}$ on average for 1-2 days in the wake of the front. The impact of the southwesterly Kaus winds blowing ahead (east) of the Shamal winds on dust emission over Iraq is also highlighted. Unlike what is observed over Iraq, low near-surface horizontal visibilities $(<1 \mathrm{~km})$ over northwest Iran are observed well after the passage of the cold front on 23 February, generally in the hours following sunrise. Ground-based lidar measurements acquired in Zanjan show that, in the wake of the front, dust from Syria/Iraq was transported in an elevated 1 to $1.5 \mathrm{~km}$ thick plume separated from the surface during the night/morning of 23 February. After sunrise, strong turbulence in the developing convective boundary layer led to mixing of the dust into the boundary layer and in turn to a sharp reduction of the horizontal visibility in Zanjan. The timing of the reduction of surface horizontal visibility in other stations over northwest Iran (Tabriz, Qom, and Tehran) is consistent with the downward mixing of dust in the planetary boundary layer just after sunset, as evidenced in Zanjan. This study sheds new light on the processes responsible for dust emission and transport over Iraq and northwest Iran in connection with winter Shamal events. Enhanced knowledge of these processes is key for improving dust forecasts in this region.

Citation: Abdi Vishkaee, F., C. Flamant, J. Cuesta, L. Oolman, P. Flamant, and H. R. Khalesifard (2012), Dust transport over Iraq and northwest Iran associated with winter Shamal: A case study, J. Geophys. Res., 117, D03201, doi:10.1029/2011JD016339.

\section{Introduction}

[2] The city of Tehran is located in the northwestern part of Iran and is bordered by the Alborz Mountains to its north and the central desert (Dasht-e Kavir) to the south (see Figure 1). This region is known to be prone to dust storms originating from both active external dust source regions (Iraq, Syria, the Turkmenistan basin) and internal dust sources (the Dasht-e Kavir desert) [Prospero et al., 2002; Abdi Vishkaee et al., 2011]. Dust storms in Iran are known to

\footnotetext{
${ }^{1}$ Laboratoire de Météorologie Dynamique, CNRS and Ecole Polytechnique, Palaiseau, France.

${ }^{2}$ Physics Department, Institute for Advanced Studies in Basic Sciences, Zanjan, Iran.

${ }^{3}$ Laboratoire Atmosphères, Milieux, Observations Spatiales, CNRS and Université Pierre et Marie Curie, Paris, France.

${ }^{4}$ Laboratoire Inter-Universitaire des Systèmes Atmosphèriques, Université Paris Est Créteil, Créteil, France.

${ }^{5}$ Department of Atmospheric Science, University of Wyoming, Laramie, Wyoming, USA.

Copyright 2012 by the American Geophysical Union. 0148-0227/12/2011JD016339
}

have an impact on public health [Miri et al., 2007] and also to affect both surface and airborne traffic [e.g., Kutiel and Furman, 2003].

[3] While the dust sources in the Middle East and in southwest Asia are particularly active in the summer [Middleton, 1986a, 1986b; Prospero et al., 2002], dust storms are also observed in the winter. Middleton [1986a, 1986b] reported an average of 30+ dust storms per annum in Hamadan, west of Tehran, with three to five storms per month being observed in the winter (January-FebruaryMarch), which is the season with the lowest number of dust events. In addition, Kutiel and Furman [2003] showed that in a broad region encompassing Iraq and Iran there is a reduction in visibility below $11 \mathrm{~km}$ (indicating the presence of aeolian dust) between $5 \%$ and $15 \%$ of the time on average during winter.

[4] Abdi Vishkaee et al. [2011] have analyzed the dynamical processes leading to dust emission over countries surrounding Iran in the summer as well as the subsequent transport of dust toward northwest Iran. They have shown the prevalent influence of the Syrian/Iraqi sources and the importance of the summer Shamal for dust mobilization over 


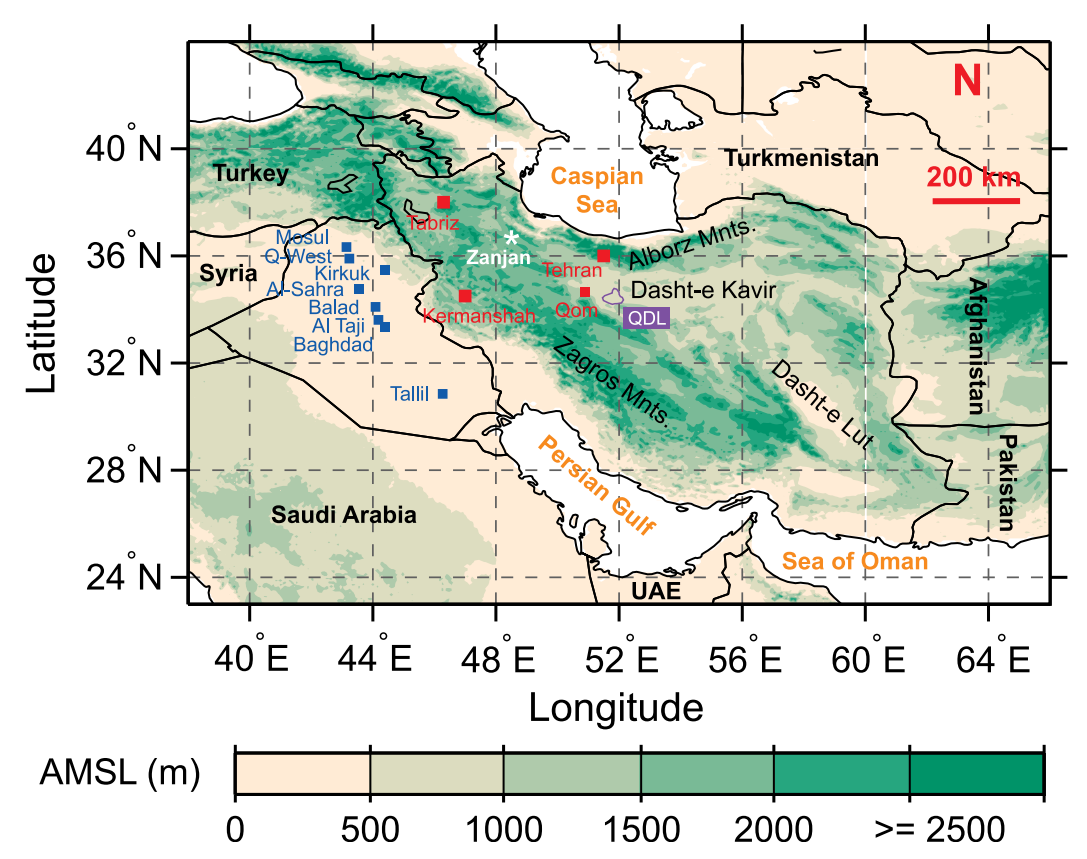

Figure 1. Map of orography in Iran as provided by the Global Land One-km Base Elevation Project (GLOBE, available from http://www.ngdc.noaa.gov/mgg/topo/globe.html). The location of Zanjan is indicated by the asterisk on the map. The locations of the cities of Tehran, Tabriz, Kermanshah, and Qom (Iran) are indicated as red squares. The locations of the cities of Al Sahra, Al Taji, Balad, Baghdad, Kirkuk and Mosul, Q-West and Tallil (Iraq) are indicated as blue squares. The location of the large intermittent salt lake called Daryacheh-ye Namak $\left(1825 \mathrm{~km}^{2}\right)$, close to the city of Qom, is also shown (QDL, Qom Dry Lake).

these countries. The word "Shamal" in Arabic literally means "north" and designates strong northwesterly winds blowing in the Persian Gulf area during the summer (June to August) and the winter (November to March) [Perrone, 1979]. The characteristics of the two seasons' Shamals are markedly different. For instance, the summer Shamal blows practically continuously while the winter Shamal can be characterized as being of two general types based on duration: those which last 24-36 $\mathrm{h}$ and those which last for a typically longer period of 3-5 days. Winter Shamal events occur as frequently as two to three times per month between December and early March [Rao et al., 2001]. Although the winter Shamal is a relatively rare event, it is known to have a greater potential than its summer counterpart for adverse weather conditions such as thunderstorms, turbulence, low visibilities, and high seas. In addition, before the onset of the Shamal, winds in the area ahead of the approaching cold front blow from the south to southeast. These southerly winds (called Kaus in Arabic) slowly increase in intensity as the front approaches and may reach gale force before the frontal passage [Perrone, 1979].

[5] The winter Shamal is associated with midlatitude disturbances that progress from west to east, and it occurs following cold frontal passages. The onset, duration, and strength of the winter Shamal winds vary depending on the dynamic interaction of upper air jet streams (i.e., the polar and subtropical jets [e.g., Perrone, 1979]) and distribution of lower tropospheric pressure zones [Ali, 1994] and particularly the relative strengths of the Indian and Arabian thermal lows [Emery, 1956]. One important difference between the 24-36 $\mathrm{h}$ and of 3-5 day Shamals is that during the shorter- duration Shamal, the upper air trough does not stall in the vicinity of the Strait of Hormuz but rather moves away quickly and smoothly to the east. As a result, the strong wind zone over the Persian Gulf area is advected southeastward with the surface cold front. This strong wind zone extends from the frontal position back to the northwest.

[6] The incursion of cold air into the Persian Gulf region from the north precedes the more intense winter Shamals. The mountains of Turkey, Georgia, and Iran provide an effective barrier to all but the most intense of these incursions. The basin-like contours of the Persian Gulf region, with sharply rising mountains to the north and east and more gradual upsloping terrain to the west and southwest, tend to direct the low-level air flow in a general northwest-southeast orientation.

[7] The winter Shamal is a wind that sets in with great abruptness and force and brings some of the strongest winds of the season to the Persian Gulf region [Hubert et al., 1983; Reynolds, 1993]. Furthermore, dust events associated with winter Shamal are generally more intense in horizontal and vertical extent than their summer counterpart [Rao et al., 2001; Perrone, 1979; Safar, 1980; Wilkerson, 1991] because of stronger interactions between the polar and subtropical jets. The strong postfrontal wind gust can reach $25 \mathrm{~m} \mathrm{~s}^{-1}$ which can reduce visibilities to a few hundred meters [Wilkerson, 1991]. Winter Shamal events are likely to mobilize large amounts of dust over the Middle East and southwest Asia (just as in the summer), thereby impairing air quality significantly in these regions.

[8] Figure 2 shows the number of occurrences of minimum daily horizontal visibility (see section 2.2 for a definition) 


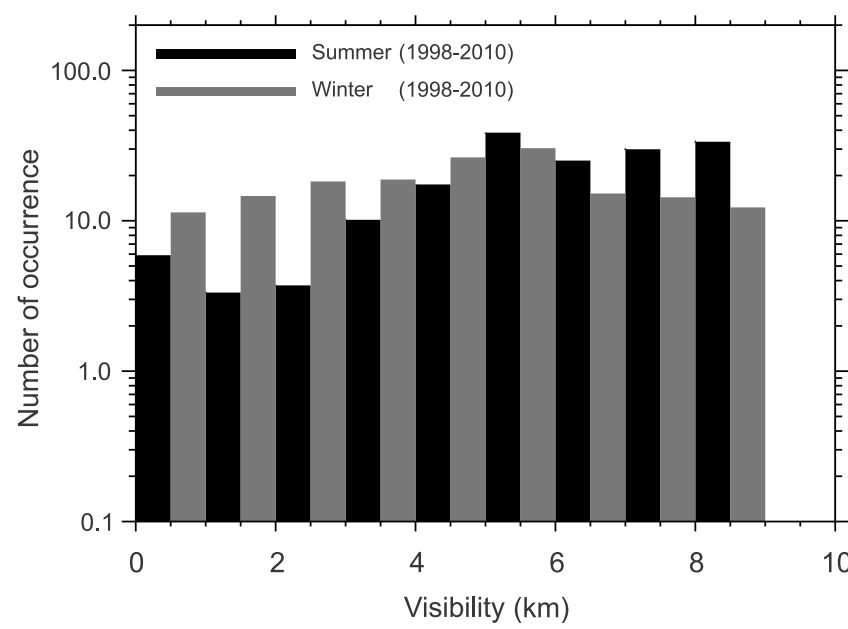

Figure 2. Number of occurrences of minimum daily horizontal visibility less than $10 \mathrm{~km}$ reported by the ground observer at Tehran meteorological station for the months of August-September (black columns) and the months of February-March (gray columns) for the period of 19982010. The total number of samples is 793 and 770 for summer and winter, respectively. The visibility data were binned in $1 \mathrm{~km}$ intervals.

less than $10 \mathrm{~km}$ in Tehran in the winter (February-March) and the summer (August-September) for the period 1998-2010. Such data are routinely reported by meteorologists. Episodes characterized by visibilities greater than $5 \mathrm{~km}$ are more numerous in the summer. On the other hand, episodes characterized by visibility less than $5 \mathrm{~km}$ are more frequently observed in the winter, and a significant number of events characterized by visibilities less than or equal to $2 \mathrm{~km}$ (generally considered to be representative of dust storms, see discussion in section 2.2) are also detected (20 in summertime and 70 in wintertime). In the winter, however, low visibility can be caused by phenomena other than dust storms, namely, fog, rain, and high levels of anthropogenic pollution. Nevertheless, the lowest visibilities (below $1 \mathrm{~km}$ ) observed in wintertime are often related to dust storms.

[9] In this paper, advantage is taken of the suite of remote sensing instruments (ground-based lidar, Sun photometer) operated at the Institute for Advanced Studies in Basic Sciences (IASBS) in Zanjan, Iran, together with spaceborne and ground-based observations as well as model analyses to analyze the origin and the vertical distribution of the dust plumes transported from Iraq to northwest Iran during a winter Shamal event. As with Tehran, the city of Zanjan (located to the northwest of Tehran, see Figure 1) is prone to dust events (aeolian dust but also dust storms) from Iraq in the winter.

[10] In this study, we show that over Iraq the sharp reduction in surface visibility is associated with gale force winds and turbulence at the leading edge of the Shamalrelated cold front. The role of Kaus winds on dust emission is also highlighted. In northwest Iran (over the Iranian plateau), we provide evidence that the reduction in visibility occurs a few hours after the passage of the leading edge of the front and in connection with downward mixing of the dust aloft into the planetary boundary layer (PBL). Hence, we shed new light on the processes responsible for dust emission and transport over Iran in connection with the winter Shamal. Enhanced knowledge of these processes is key for improving dust forecasts in this region.

[11] The 22-23 February 2010 case is selected on the basis of lidar data quality and availability. The lidar observations are key to analyzing the role the PBL turbulence on the downward mixing of dust aloft toward the surface, thereby being an important link with the surface visibility observations. Note that the lidar data set for this case is the most comprehensive data set in our possession. Furthermore, the Iranian news agencies such as Mehr and IRINN have reported that five provinces of western Iran (Lorestan, Kordestan, Kermanshah, Ilam, and western Azerbaijan) were buried under a thick "blanket" of dust on Tuesday, 23 February 2010. Evening schools in Kordestan province were closed on that day, while the dust storm in Kermanshah province forced provincial authorities to close schools, universities, offices, and public organizations in all areas except in the east [Barrie and Nickovic, 2010]. To the best of the authors' knowledge, the case study presented here is representative of the winter dust plumes associated with Shamal winds over the study region.

\section{Data}

\subsection{Surface-Based Remote Sensing Measurements in Zanjan}

[12] In this study all measurements performed in Zanjan $\left(36.7^{\circ} \mathrm{N}, 48.5^{\circ} \mathrm{E}\right)$ are located at $1800 \mathrm{~m}$ above mean sea level (amsl) at IASBS. A combination of colocated instruments, a Sun photometer, and a backscatter lidar [Khalesifard et al., 2005; Abdi Vishkaee et al., 2011] is used to investigate the vertical distribution and the optical properties of aerosols over Zanjan.

[13] The CIMEL Sun photometer (model CE318-2) measures the aerosol optical depth (AOD) at five wavelengths $(440,670,870,936$, and $1020 \mathrm{~nm})$ [Bayat et al., 2011]. It has been operational since 2006, and it has been part of the Aerosol Robotic Network (AERONET) since December 2009. The instrument is calibrated using PHOTONS (http:// loaphotons.univ-lille1.fr/photons/) calibration facilities in Lille. This procedure yields an estimated wavelength-dependent accuracy of 0.01-0.02 for the absolute AOD error [Dubovik et al., 2000]. The Angström exponent computed between 440 and $870 \mathrm{~nm}$ using level 2.0 AOD data available from AERONET is also used in this paper. This exponent is inversely related to the average size of the particles in the aerosol: the smaller the particles, the larger the exponent. Numerous works showed that when desert dust particles are present, the Angström exponent generally ranges between 0 and 0.5 as, for instance, over Africa [e.g., Holben et al., 1991].

[14] The profiles of atmospheric extinction coefficient at $532 \mathrm{~nm}$ are retrieved using a standard lidar inversion technique [Fernald et al., 1972; Fernald, 1984; Cuesta et al., 2008]. Vertical and temporal resolutions of the lidar reflectivity profiles shown in this study are $24 \mathrm{~m}$ and $1 \mathrm{~min}$, respectively, the latter being obtained after averaging 1200 individual laser shots acquired at a repetition rate of $20 \mathrm{~Hz}$. The profiles of molecular extinction coefficient used in the inversion procedure are obtained from molecular density profiles computed using temperature and pressure data from balloon soundings 
launched from the nearby Tehran airport. The aerosol backscatter-to-extinction ratio (BER) used for the inversion is considered to be constant with altitude (multiple scattering associated with dust plumes for a zenith pointing groundbased lidar system is neglected). We use a backscatter-toextinction value of $0.014 \mathrm{sr}^{-1}$ in order for the lidar-derived AOD to match that derived from the Sun photometer (on average between 04:40 and 08:20 UTC). This value is close to that obtained by Kaufman et al. [2003] for Saharan dust particles (i.e., $0.016 \mathrm{sr}^{-1}$ ). For inversion, a backscatter ratio (the total backscatter coefficient divided by the molecular backscatter coefficient) of 1 is considered at $4.5 \mathrm{~km}$ above ground level (agl), i.e., above dust observed during the period of interest. Numerical sensitivity studies have shown an uncertainty of $2 \%$ in the lidar-derived AOD when neglecting aerosol layers at the normalization altitude (i.e., $4.5 \mathrm{~km}$ agl) with a particle backscatter coefficient of $10 \%$ of the molecular backscatter coefficient. Additionally, a geometrical correction is also applied to the backscatter signal below $500 \mathrm{~m}$ agl, i.e., the altitudes below which the lidar signal is not fully recovered by the overlap of the telescope field of view and laser beam [e.g., Cuesta et al., 2008]. We have estimated the full overlap height at around $0.5 \mathrm{~km}$ agl, as the lowest peak of the attenuated backscatter profiles in the mixing layer (from the surface and up to 1 to $1.5 \mathrm{~km}$ agl) occurs during the afternoon. To compensate for the overlap effect, we first linearly extrapolate below $0.5 \mathrm{~km}$ agl the profile of average attenuated backscatter coefficient between 0.5 and $0.8 \mathrm{~km}$ agl (where the average profile varies almost linearly). We derive the overlap factor as the ratio between the extrapolated and nonextrapolated attenuated backscatter coefficients below $0.5 \mathrm{~km}$ agl. Then we apply this factor to each profile of the time series. After the correction, we extrapolate each profile from $100 \mathrm{~m} \mathrm{agl}$ and down to the surface (for the blind zone of the lidar system). Because of these estimations, the uncertainty of the lidar-retrieved AOD is $6 \%$ for the total column (and 17\% below $0.5 \mathrm{~km}$ agl), assuming an uncertainty of the full overlap height of $\pm 100 \mathrm{~m}$. The uncertainty of the extinction coefficient and of the lidar-derived AOD for the total column is on the order of $30 \%$, accounting for an uncertainty of $20 \%$ on the backscatter-to-extinction ratio (we assume it to be constant in altitude following Tesche et al. [2009]), the backscatter ratio values at the normalization height, and the overlap correction. Between the surface and $500 \mathrm{~m}$ agl, the total uncertainty for the lidar-derived AOD is about $18 \%$ (only affected by $2 \%$ and $5 \%$ owing to normalization errors and uncertainties in the backscatter to extinction ratio, respectively).

\subsection{Regional Networks}

[15] The Iranian Meteorological Service operates a dense network of surface meteorological stations (more than 200 stations including synoptic and climatology stations, based on a report by http://www.irimo.ir/) that monitors horizontal visibility and meteorological observations throughout the country. Measurements performed by automatic weather stations in Kermanshah, Qom, Tabriz, Tehran, and Zanjan, Iran (see Figure 1 for locations), are used in this study (the data are available from http://www.irimo.ir). The Zanjan meteorological station is located $\sim 1 \mathrm{~km}$ from the IASBS. We also use meteorological measurements provided by U.S. military stations in Al Sahra, Al Taji, Baghdad, Balad, Kirkuk, Mosul, Q-West, and Tallil, Iraq (see Figure 1, available from http:// weather.uwyo.edu/). These stations report surface data including pressure, temperature, humidity, and wind speed and direction. The visibility observations in Iraq and Iran are taken by observers looking at landmarks. Currently, human observers compile visibility reports based on visual observation of known landmarks (prominent structures like buildings, mountain tops, etc.). This procedure is naturally very subjective to the individual observer and is error prone. The errors of visibility estimate an increase proportional to the visibility, and the measurement scales take this into account. Because visibility observations are very much dependent on the observer, such measurements may not be comparable from station to station. Nevertheless, time series derived at a given station are expected to be self-coherent, and low visibilities associated with specific meteorological conditions are expected to be reported consistently from one event to the next. In the winter time, low visibility can be caused by fog, rain, and high anthropogenic pollution levels. It is also an indication of the presence of high dust loads in the lower atmosphere in the case of dust storms.

[16] In this paper, dust storms are considered to be associated with visibility values of $2 \mathrm{~km}$ or less, such as those of Abdi Vishkaee et al. [2011]. This threshold value on visibility enables us to account for both strong events occurring over dust source regions in Iraq (in which case, visibility is expected to be less than $1 \mathrm{~km}$ [Middleton, 1986b]) and the visibility resulting from long-range transports over Iran (which are in the range 2-9 km) [Mahowald et al., 2007]. In the case of propagating dust storms, the arrival of airborne dust at a given site is generally associated with a significant decrease in visibility and high wind speed. Because smog in big cities (e.g., Tehran) and fog reduce the visibility significantly in the winter, wind speed is an important criterion for segregating between $\mathrm{smog} / \mathrm{fog}$ and dust storm events. At the other end of the spectrum, visibility values above $10-12 \mathrm{~km}$ are considered to be representative of clean air conditions. Values of visibility ranging from 3 to $10 \mathrm{~km}$ can therefore be associated with more or less thick aeolian dust plumes as well as moderate pollution events.

[17] Finally, the Shamal cold front crossing time considered at each of the 13 stations is derived using the following criteria (at least five out of the six must be met): (1) a decrease in water vapor mixing ratio, (2) a decrease in temperature, (3) a increase of pressure, (4) northeasterly winds, (5) a wind surge (in excess of $6 \mathrm{~m} \mathrm{~s}^{-1}$ ), and (6) a sharp reduction of the visibility $\left(\sim 3 \mathrm{~km} \mathrm{~h}^{-1}\right.$ or more). Likewise, the Kaus wind over Iraq is detected with a wind surge $\left(6 \mathrm{~m} \mathrm{~s}^{-1}\right)$, south or southwesterly winds, an increase in temperature, a reduction of visibility, and a decrease of pressure.

\subsection{Spaceborne Observations}

[18] The regional distribution of dust aerosols (mobilization and transport) is described using two complementary satellite products. First, the Moderate Resolution Imaging Spectroradiometer (MODIS) fields of AOD are obtained from the MODIS/AQUA Deep Blue Collection 005 over desert surfaces (MOD08 product). Only the daily level 3 AOD product at $550 \mathrm{~nm}$ processed with the deep blue algorithm [Hsu et al., 2004] available from the Giovanni Web portal (http://disc.sci.gsfc.nasa.gov/giovanni) is used. The MODIS AOD product used in this study is a level 3, gridded $\left(1^{\circ} \times 1^{\circ}\right)$, daily product, representative of the 
aerosol load at midday. Comparisons between the Deep Blue and AERONET AODs are generally within 20-30\% of each other, as demonstrated by Salustro et al. [2009, 2010] using AQUA collection 5.1 data from July 2002 to December 2008 over the Sahara as well as the Arabian Peninsula. Second, the vertical distribution of the aerosols is documented at the regional scale using the spaceborne Cloud-Aerosol Lidar with Orthogonal Polarization (CALIOP) [Winker et al., 2007] on board the Cloud-Aerosol Lidar and Infrared Pathfinder Satellite Observations (CALIPSO) satellite.

[19] CALIOP-derived profiles of particle extinction coefficient (at $532 \mathrm{~nm}$ ) are obtained from our own calculation (using level 1B version 2 data) as that by Cuesta et al. [2009] and Messager et al. [2010], with a vertical resolution of $60 \mathrm{~m}$ and a horizontal resolution of roughly $12 \mathrm{~km}$. We expect the uncertainty on the extinction coefficient and on the AOD to be on the order of $30 \%$, accounting for an uncertainty of $20 \%$ on both the BER and the multiple scattering coefficients. Data from two daytime overpasses are used to analyze the case: around 10:35 UTC on 22 February as well as around 09:39 UTC on 23 February.

\subsection{Reanalysis Data and Backward Trajectories}

[20] Synoptic-scale meteorological conditions are established using 6-hourly Interim reanalyses of European Centre for Medium-range Weather Forecasts (ECMWF) for horizontal winds and potential temperature at the surface, 800 , and $400 \mathrm{hPa}$. The resolution of reanalyses for the region covering the Middle East is about $0.75^{\circ}$ [Dee et al., 2011]. Wind speeds issued from the reanalyses can provide valuable information regarding the potential activation of given dust sources at the regional scale. Equivalent potential temperature charts at $800 \mathrm{hPa}$ are used to track the propagation of the cold front across Iraq and Iran. While the $800 \mathrm{hPa}$ charts do not reproduce exactly the progression of the cold front at the surface, they provide the realistic framework for analyzing the westerly displacement of the cold air associated with winter Shamal during the event. Note that surface charts could not be used to depict the propagation of the front because of the presence of numerous topographic features and because of the mean elevation of Iran. For instance, the signal in the surface equivalent potential temperature charts appeared to be biased toward elevated terrain. This strongly impairs our capacity for objectively (or even subjectively) tracking the cold front across Iraq and Iran.

[21] The dust transport patterns between the source regions and Zanjan are assessed from back trajectory analyses using the HYSPLIT (Hybrid Single-Particle Lagrangian Integrated Trajectory) model (http://ready.arl.noaa.gov/HYSPLIT_traj. php) [Draxler and Rolph, 2003; Rolph, 2003] retrieved from the NOAA READY Web site (http://www.arl.noaa.gov/ready. html). Following Abdi Vishkaee et al. [2011], in order to account for the inherent uncertainty of trajectory calculations, the backward trajectories are calculated as ensembles arriving within a specific arrival domain. The start point altitudes and times for the backward trajectories are defined on the basis of the ground-based lidar observations.

[22] Finally, since ECMWF reanalyses are used for looking at synoptic circulation and National Centers for Environmental Prediction (NCEP) reanalyses are used for running the HYSPLIT model, the consistency between the two reanalyses is crucial. Comparison among wind fields from the
NCEP and ECMWF at $10 \mathrm{~m} \mathrm{agl,} 800 \mathrm{hPa}$, and $400 \mathrm{hPa}$ highlights the coherence between the two reanalyses (not shown).

\section{The 22-23 February 2010 Case}

\subsection{Synoptic Setting}

[23] On 22 February, ECMWF reanalyses show that an upper trough is reflected in a surface low advected over Turkey, as well as northern Syria and Iraq, from the eastern Mediterranean area (06:00 UTC, Figure 3a). While the upper trough and associated surface low move eastward, a surface cold front extends south, then west from the low (Figure 3c). The strong northwesterly winds of the Shamal form at and behind the cold front (Figure 3b). The Kaus occurs over Saudi Arabia in the warm air ahead of the cold front (Figure 3c).

[24] On 22 February at 18:00 UTC, the upper trough has moved to the east and its southern part is now located over northern Iran (Figure 4a) while cold, dry air spreads over Iraq and northwest Iran (Figure 4b). At 06:00 UTC on 23 February, the upper trough and related surface low are now east of Iran (Figure 4c). Cold air masses at $800 \mathrm{hPa}$ are now seen to lie across Iraq, northern Iran, and part of Turkmenistan (Figure 4d). As the front propagates southeastward, increasingly colder and drier air spreads over Iraq, as observed at the surface in all Iraqi stations (not shown).

\subsection{Propagation of the Winter Shamal Cold Front and Related Dust Storms Over Iraq}

[25] On the basis of the charts of $800 \mathrm{hPa}$ equivalent potential temperature shown in Figures $3 \mathrm{c}, 4 \mathrm{~b}$, and $4 \mathrm{~d}$, it appears that the cold front is oriented northeasterly/southwesterly and that it propagates eastward. This is confirmed by our analysis of the cold front crossing times at each of the 13 stations considered in this study (see Table 1).

[26] Figure 5 shows the southeastward propagation of the cold front from Al Sahra to the north and Tallil to the south of Iraq, between 04:50 and 14:00 UTC on 22 February. In Al Sahra, the strongest observed winds are associated with the cold front. A very sharp decrease of the visibility $(10 \mathrm{~km}$ to a few tens of meters in $2 \mathrm{~h}$ ) is observed, following strong surface wind surges $\left(\sim 9 \mathrm{~m} \mathrm{~s}^{-1}\right.$, Figure $\left.5 \mathrm{a}\right)$. This behavior is an indication of the arrival of the leading edge of a propagating dust storm [e.g., Miller et al., 2008]. In the other stations, the strongest wind surges are observed to be associated with the Kaus wind blowing ahead of the cold front (Figures 5b-5d). Nevertheless, the passage of the cold front in Kirkuk (Figure 5b), Al Taji (Figure 5c), and Tallil (Figure 5d) is also associated with strong winds, in excess of $8 \mathrm{~m} \mathrm{~s}^{-1}$. At these stations, a decrease of the surface horizontal visibility is first observed to be associated with the Kaus wind, then a second decrease is observed in relationship with the Shamal. In Kirkuk (Figure 5b), the peak of Kaus and Shamal winds are separated by $2 \mathrm{~h}$, and the strong Kaus winds reduce the visibility from 10 to $6 \mathrm{~km}$, while the strong winds at the leading edge of the front further decrease the visibility from 6 to $0.2 \mathrm{~km}$. The lag between the Kaus and cold front surges increases to 9 and $12 \mathrm{~m} \mathrm{~s}^{-1}$ in Al Taji and Tallil, respectively (Figures $5 \mathrm{c}$ and $5 \mathrm{~d}$ ). In Al Taji, the Kaus surge reduces the horizontal surface visibility from 10 to $5 \mathrm{~km}$, the visibility reaching $0.2 \mathrm{~km}$ after the passage of the cold front (Figure 5c). Finally, the largest decrease in 

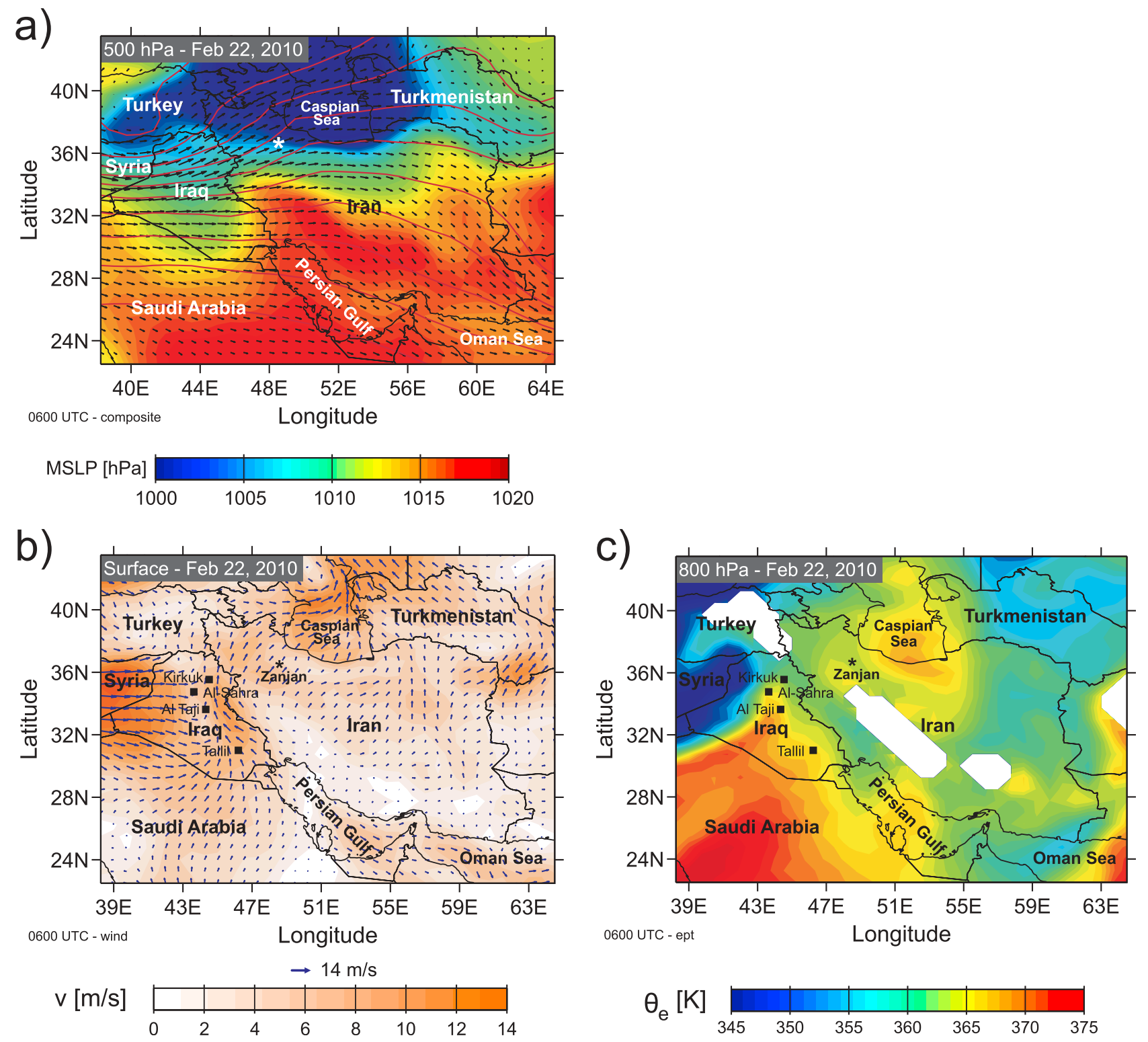

Figure 3. (a) ECMWF analysis of mean sea level pressure (color), $500 \mathrm{hPa}$ geopotential height (solid lines) and $500 \mathrm{hPa}$ horizontal winds (vectors) on 22 February 2010 at 06:00 UTC. (b) Same as Figure 3a but for $10 \mathrm{~m}$ winds (agl). (c) Same as Figure 3a but for equivalent potential temperature at $800 \mathrm{hPa}$. White areas in Figure 3c correspond to orography mask in the ECMWF ERA-Interim reanalyses.

visibility associated with the Kaus wind is observed in Tallil, where the visibility reduces to $0.2 \mathrm{~km}$ in less than $2 \mathrm{~h}$ (Figure 5d). The visibility increases slightly after the Kaus surge and prior to the arrival of the cold front, reaching $2.5 \mathrm{~km}$. It then decreases to $0.2 \mathrm{~km}$ after the passage of the cold front.

[27] The dust mobilized at the leading edge of the front when passing over a dust source is trapped in the closed circulation behind the front [e.g., Goff, 1976; Simpson, 1987; Adlerman et al., 1999] and therefore can be transported over large distances as long as the density difference across the front is significant. The visibility in most cities is reduced to $200 \mathrm{~m}$ or less at the leading edge of the dust storm, and the period during which the visibility is less than $2 \mathrm{~km}$ varies between $24 \mathrm{~h}$ (Al Taji) and $48 \mathrm{~h}$ (Kirkuk, Tallil). The reason for the low visibility over the stations after the passage of the leading edge of the dust storm is likely related to the weak surface winds behind the front (as seen in Figures 5a-5d) preventing the mobilized dust from advecting out.

[28] ECMWF reanalyses at 06:00 UTC on 22 February (Figure $3 b$ ) show that the Shamal surface winds over Syria and Iraq are in excess of $6 \mathrm{~m} \mathrm{~s}^{-1}$ and have the potential to activate dust sources, as is the case in other deserts when surface winds exceed that threshold [Pye, 1987]. This is confirmed by the MODIS-derived AOD field on 22 February which shows an area characterized by values in excess of 1 over northern Iraq (Figure 6a) consistent with dust source activation. Cloud cover over most of Iraq and northern Iran prevents the retrieval of the AOD in this area (white areas are where no value could be determined). Nevertheless, the 

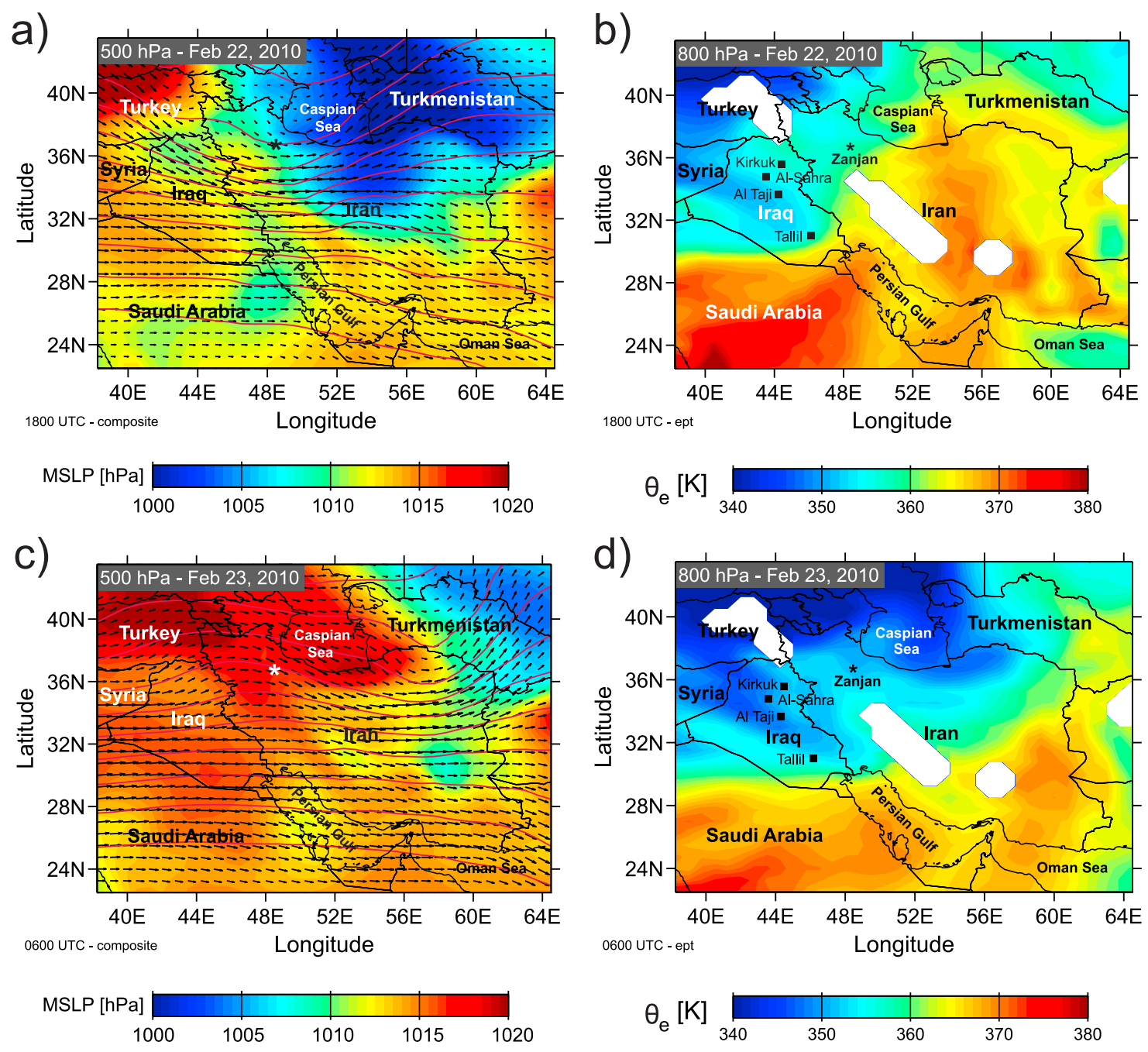

Figure 4. (a) ECMWF analysis of mean sea level pressure (color), $500 \mathrm{hPa}$ geopotential height (solid lines) and $500 \mathrm{hPa}$ horizontal winds (vectors) on 22 February 2010 at 18:00 UTC. (b) Same as Figure 4a but for equivalent potential temperature at $800 \mathrm{hPa}$.(c) Same as Figure 4a but on 23 February 2010 at 06:00 UTC. (d) Same as Figure 4c but for equivalent potential temperature at $800 \mathrm{hPa}$. White areas in Figures $4 \mathrm{~b}$ and $4 \mathrm{~d}$ correspond to orography mask in the ECMWF ERA-Interim reanalyses.

dense plume of dust sweeping from Syria into Iraq on 22 February can be seen on the true-color image captured by MODIS imager in the early afternoon (Figure 6b). Distinct plumes rise from many individual sources in the Syrian desert. Within a few kilometers, the plumes blend into a dense cloud that completely obscures eastern Syria and western Iraq. The veil of dust is thick enough that the ground beneath is not visible.

[29] Daytime CALIOP measurements on 22 February (Figure 6c) corroborate the large AOD values observed with MODIS over Iraq (AODs reaching 1 between $31^{\circ} \mathrm{N}$ and $32^{\circ} \mathrm{N}$ ) and provide insight into the vertical structure of the aerosol plume south of $32^{\circ} \mathrm{N}$. Aerosols are observed to be well mixed in a rather shallow layer, approximately 1$1.5 \mathrm{~km}$ deep over Iraq (Figure 6d). In comparison, the depth of the PBL in the same region can reach $3.5-4 \mathrm{~km}$ in the summertime, as shown by Abdi Vishkaee et al. [2011]. North of $33^{\circ} \mathrm{N}$, a thick deck of clouds is observed at the top of the PBL (water clouds are associated with very large values of the extinction coefficient and appear in white in Figure 6d) which prevents retrievals of lidar extinction coefficient in the lower levels.

\subsection{Propagation of the Winter Shamal Cold Front and Related Dust Storms Over Northwest Iran}

[30] In this section, we detail the propagation of the cold front and of the dust plume over northwest Iran in connection with surface visibility observations. The main reason we present the observations from the Iranian stations separately from the Iraqi stations is related to the processes underpinning the relationship between the cold front propagation and surface horizontal visibility, as now discussed. This relationship is connected to the diurnal cycle of the PBL and solar radiation and hence to local time. As a result, we shall mention both UTC and local time (LT) when discussing data over Iran in connection with PBL processes.

[31] The arrival of the cold front in Tabriz to the north occurs around 08:30 UTC (Table 1) in the morning of 22 February (Figure 7a). The passage of the cold front is associated with a wind surge of $9 \mathrm{~m} \mathrm{~s}^{-1}$ and an increase of 
Table 1. Winter Shamal-Related Cold Front Crossing Time at Each of the Eight Iraqi and Five Iranian Stations ${ }^{\mathrm{a}}$

\begin{tabular}{lccc}
\hline \multicolumn{1}{c}{ Station } & $\begin{array}{c}\text { Position Latitude, } \\
\text { Longitude }\end{array}$ & $\begin{array}{c}\text { Time } \\
(\text { UTC) }\end{array}$ & $\begin{array}{c}\text { Wind Speed } \\
\left(\mathrm{m} \mathrm{s}^{-1}\right)\end{array}$ \\
\hline Mosul (Iraq) & $43.14^{\circ} \mathrm{E}, 36.33^{\circ} \mathrm{N}$ & $04: 20$ & 8 \\
Q-West (Iraq) & $43.14^{\circ} \mathrm{E}, 36.04^{\circ} \mathrm{N}$ & $04: 50$ & 12 \\
Al Sahra (Iraq) & $43.55^{\circ} \mathrm{E}, 34.76^{\circ} \mathrm{N}$ & $04: 50$ & 9 \\
Kirkuk (Iraq) & $44.39^{\circ} \mathrm{E}, 35.47^{\circ} \mathrm{N}$ & $07: 10$ & 8 \\
Tabriz (Iran) & $46.27^{\circ} \mathrm{E}, 38.07^{\circ} \mathrm{N}$ & $08: 30$ & 9 \\
Balad (Iraq) & $44.08^{\circ} \mathrm{E}, 34.09^{\circ} \mathrm{N}$ & $09: 35$ & 6 \\
Al Taji (Iraq) & $44.25^{\circ} \mathrm{E}, 33.52^{\circ} \mathrm{N}$ & $12: 00$ & 8 \\
Baghdad (Iraq) & $44.39^{\circ} \mathrm{E}, 33.32^{\circ} \mathrm{N}$ & $13: 10$ & 6 \\
Tallil (Iraq) & $46.13^{\circ} \mathrm{E}, 30.97^{\circ} \mathrm{N}$ & $14: 10$ & 9 \\
Kermanshah (Iran) & $47.12^{\circ} \mathrm{E}, 34.27^{\circ} \mathrm{N}$ & $14: 25$ & 12 \\
Zanjan (Iran) & $48.48^{\circ} \mathrm{E}, 36.66^{\circ} \mathrm{N}$ & $14: 30$ & 15 \\
Qom (Iran) & $50.84^{\circ} \mathrm{E}, 34.65^{\circ} \mathrm{N}$ & $16: 50$ & 15 \\
Tehran (Iran) & $51.35^{\circ} \mathrm{E}, 35.34^{\circ} \mathrm{N}$ & $18: 00$ & 13 \\
\hline
\end{tabular}

${ }^{a}$ The wind speed of the front-related surges at the time of the crossing is also given.

visibility, likely because the front does not encounter any active dust source over northwest Iran (or farther north). A large decrease of horizontal visibility from 10 to $0.1 \mathrm{~km}$ occurs around 07:00 UTC (10:30 LT) on 23 February, nearly $24 \mathrm{~h}$ after the passage of the cold front. This decrease is not associated with a wind surge but rather with light winds $\left(\sim 3 \mathrm{~m} \mathrm{~s}^{-1}\right)$. Likewise, in Zanjan and Qom (Figures $7 \mathrm{~b}$ and $7 \mathrm{c}$ ), a marked decrease of surface horizontal visibility (of at least $7.5 \mathrm{~km}$ in $2 \mathrm{~h}$ ) occurs nearly $12 \mathrm{~h}$ after the wind surges of $\sim 15 \mathrm{~m} \mathrm{~s}^{-1}$ associated with the cold front. The decrease in visibility is observed at 03:00 UTC (06:30 LT) in Zanjan (Figure 7b) and at 04:50 UTC (08:20 LT) in Qom (Figure 7c) on the 23 February. In Zanjan, the fact that visibility is unaffected at the time of the wind surge likely means that no significant surface dust load is transported by the leading edge of the cold front, unlike what is observed over Iraq (Figure $7 b$ ). Finally, the arrival of the cold front in Tehran is observed between 18:00 UTC on 22 February and 01:00 UTC on 23 February and is associated with a sharp reduction in visibility (from 10 to $5 \mathrm{~km}$ and then from 5 to $1 \mathrm{~km}$ ) shortly afterward (Figure 7d). The lowest visibilities in Tehran $(\sim 0.2 \mathrm{~km})$ are observed around 04:50 UTC (08:20 LT), a time when the winds are lightest.

[32] According to ECMWF analyses, the cold front lies over central Iran on 23 February at 06:00 UTC (Figure 3d), well south of Zanjan, Qom, and Tehran. On that day, clouds prevent MODIS AOD retrievals over most of Iraq (also white areas in Figure 8a). However, a distinct aerosol plume is observed over the Dasht-e Kavir desert region in northern Iran. The eastern edge of the plume is also identifiable in the CALIOP data around $33^{\circ} \mathrm{N}, 57^{\circ} \mathrm{E}$ as enhanced extinction coefficients in the lowest $1 \mathrm{~km}$ (Figure 8c), leading to maximum AOD values on the order of 0.5 (Figure 8b), in fair agreement with the MODIS retrievals $(\sim 0.6)$. As the surface winds over northwestern Iran are mostly northwesterly, the a) AI Sahra

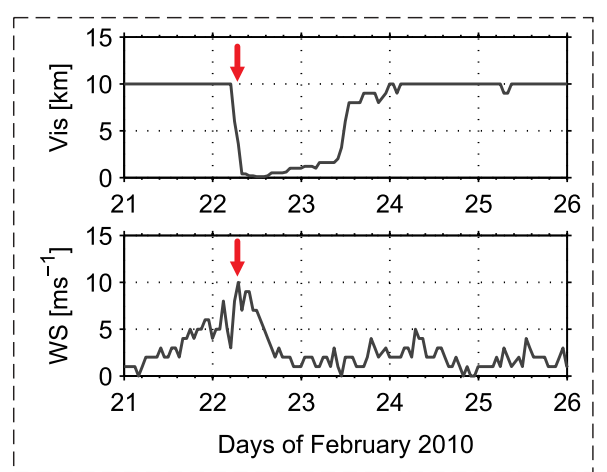

c) Al Taji

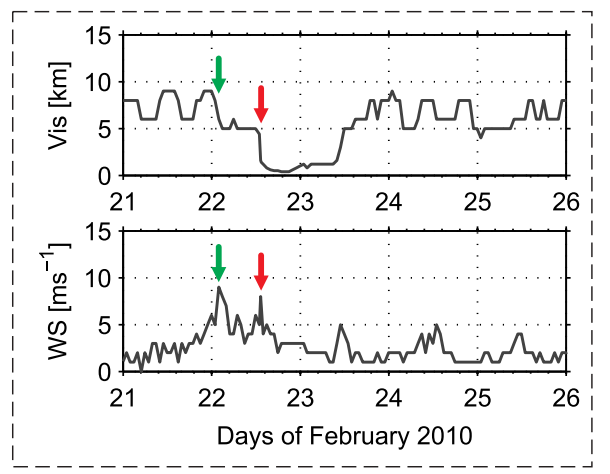

b) Kirkuk

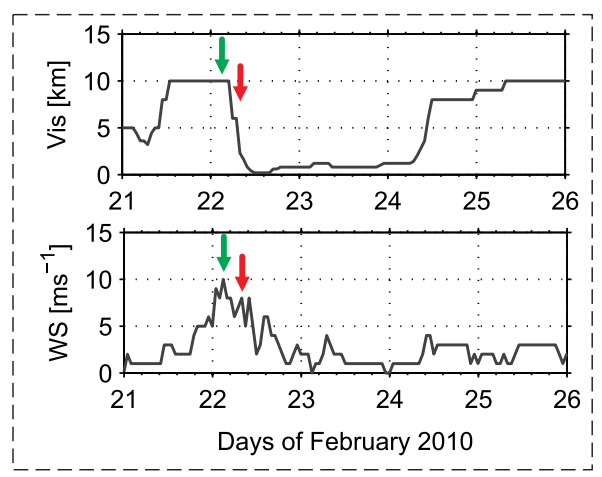

d) Tallil

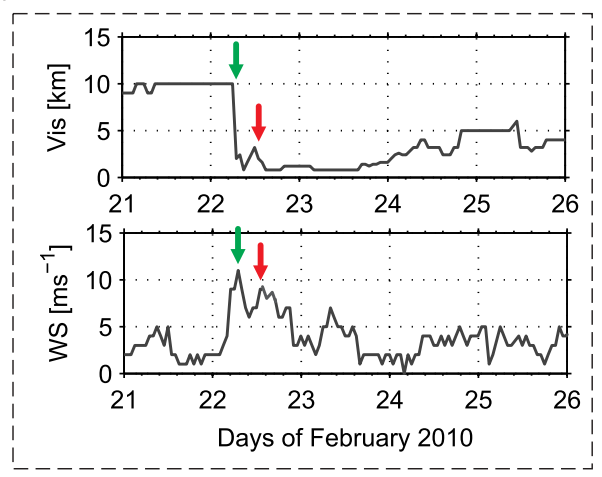

Figure 5. Hourly horizontal visibility (Vis, top) in $\mathrm{km}$ and wind speed (WS, bottom) in $\mathrm{m} \mathrm{s}^{-1}$ for the period of 21-26 February 2010 measured in Iraq in (a) Al Sahra, (b) Kirkuk, (c) Al Taji and (d) Tallil (see Figure 1 for the locations of the stations). Green arrows indicate the time of the Kaus wind surges at the stations. Red arrows indicate the winter Shamal-related cold front crossing time at the stations (also see Table 1). 

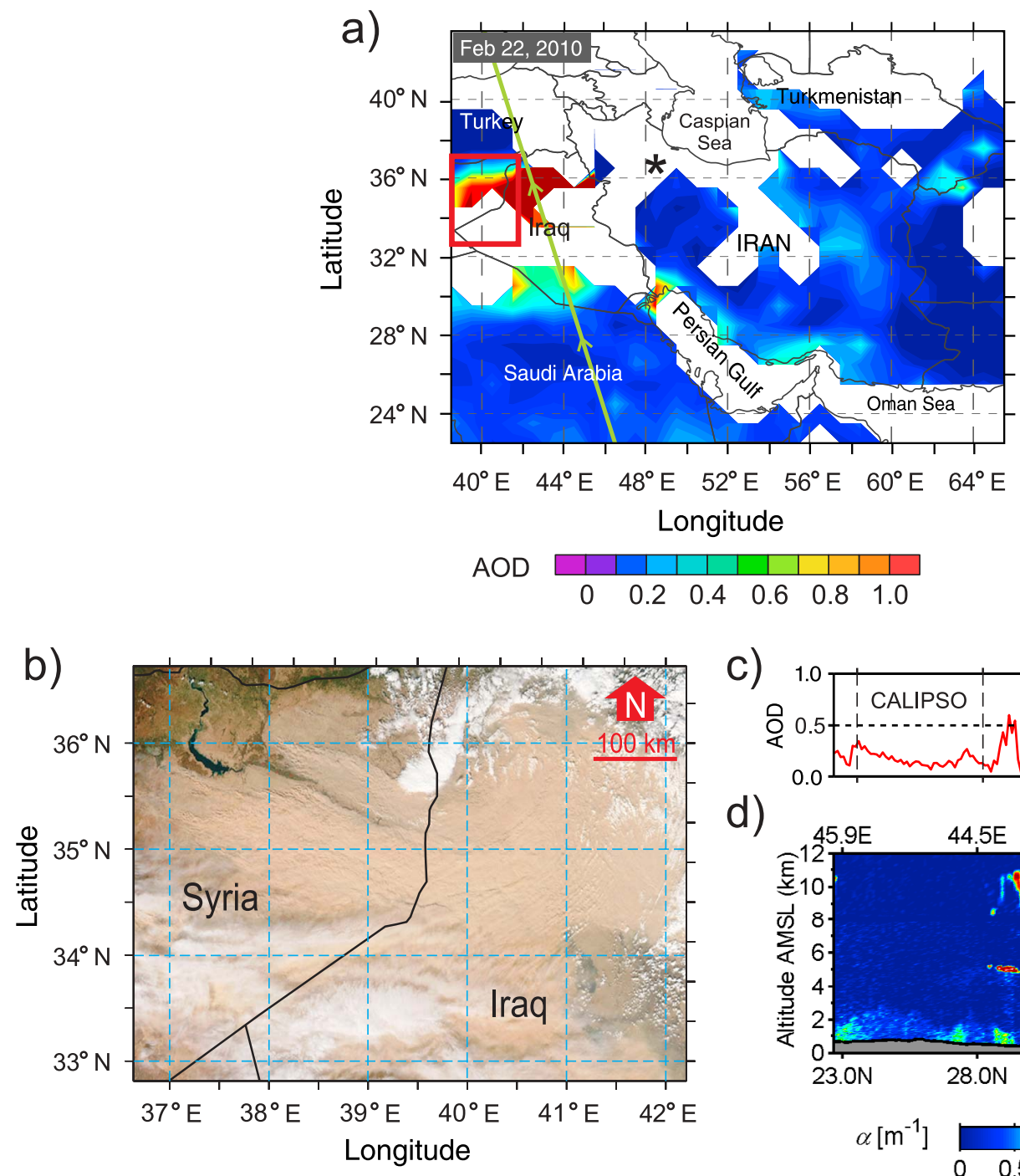

c)

)

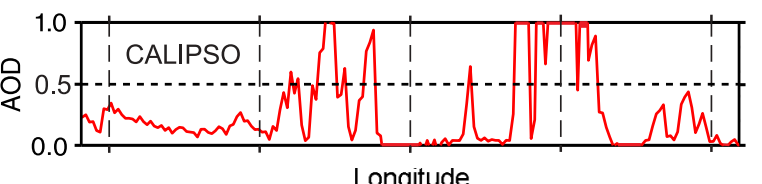

d)

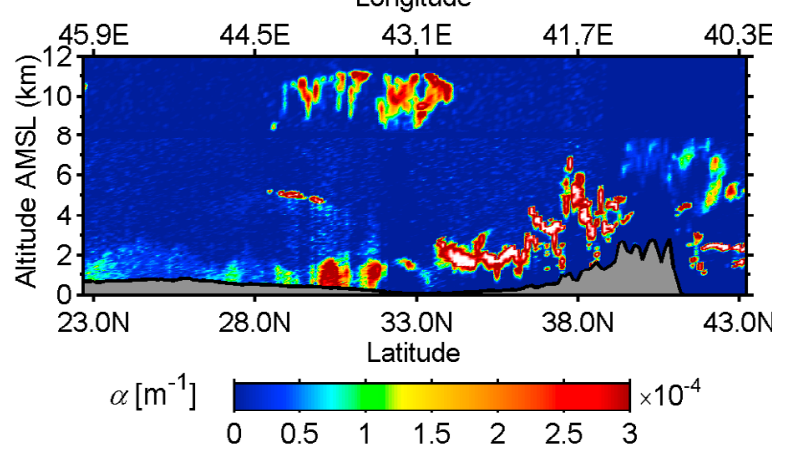

Figure 6. (a) MODIS Deep Blue AOD at $550 \mathrm{~nm}$ on 22 February 2010. (White areas are where no value could be determined). The location of Zanjan is marked with an asterisk. The daytime CALIPSO track is also overlaid as a solid green line. (b) True-color image of the dust storm was captured by MODIS imager in the early afternoon over Syria and Iraq on 22 February (13:30 LT in Iraq, 14:00 LT in Iran, 10:30 UTC). This region is marked as a red square in Figure 6a. (c) CALIOP-derived AOD along the CALIPSO track (solid red line) around 10:35 UTC on 22 February 2010. (d) Vertical cross section of CALIOP particle extinction coefficient (at $532 \mathrm{~nm}$ ) around 10:35 UTC on 22 February 2010.

large AOD values could be due to (1) dust mobilization at the leading edge of the cold front as it passed over the dry lake at the western edge of the Dasht-e Kavir desert, a dust source known to be active in the summer [Abdi Vishkaee et al., 2011] and (2) the dust storm from Iraq. In Figure 7c, the $5 \mathrm{~km}$ surface horizontal visibility decrease observed at the Qom meteorological station located near the dry lake (a large intermittent salt lake called Daryacheh-ye Namak, $\sim 1825 \mathrm{~km}^{2}$, see Figure 1) is consistent with dust activation over the dry lake by the leading edge of the cold front. Also, HYSPLIT-derived backward trajectories starting over the region of high AOD values in Iran at 08:00 UTC on 23 February (Figure 8d) indicate that the air masses between 0.5 and $1.5 \mathrm{~km}$ have traveled over northern Tehran and northern Iran a few hours before being present over the Dasht-e Kavir desert and over northern Iraq on the previous day.
[33] In summary, over the Iranian plateau, the reduction in visibility occurs a few hours after the passage of the leading edge of the front, as opposed to what is observed over Iraq where the reduction of visibility is concomitant with the time of arrival of the front leading edge. A notable exception is the station of Kermanshah in Iran, located on the western slopes of the Zagros Mountains, where the reduction in surface horizontal visibility is observed to coincide with the arrival of the leading edge of the cold front (not shown). Another difference is the signature of the Kaus (a southerly wind) blowing ahead of the approaching cold front which is observed over Iraq but not over Iran.

[34] In the following, we analyze the processes underpinning the relationship between the cold front propagation and surface horizontal visibility, in connection with the diurnal 
a) Tabriz

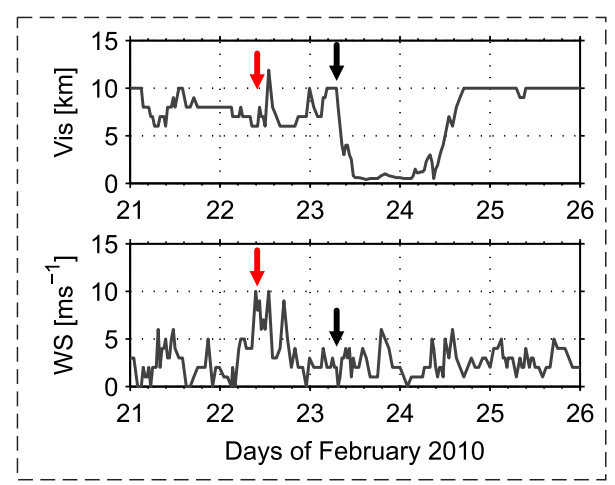

c) Qom

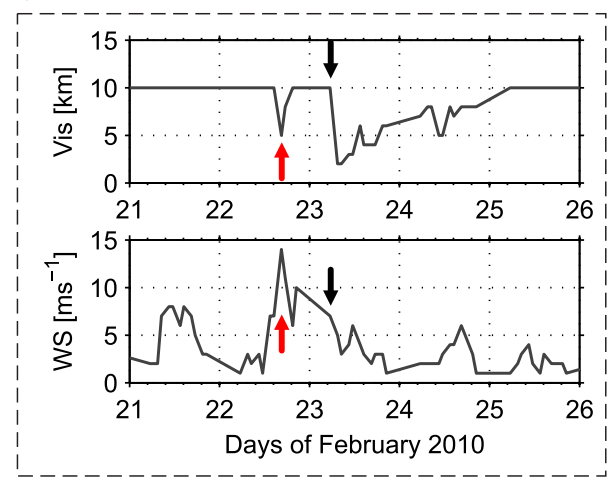

b) Zanjan

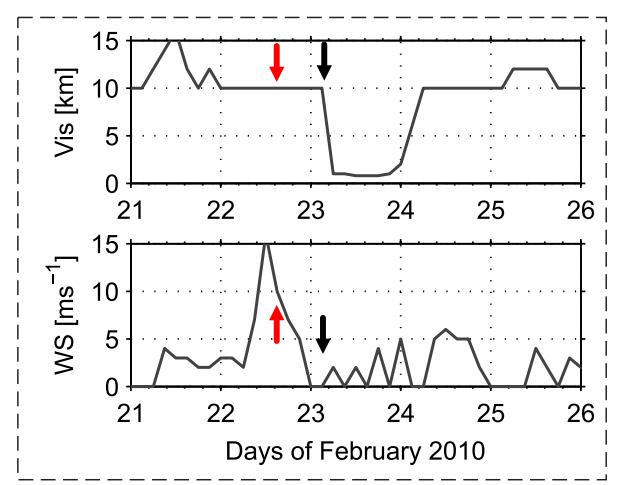

d) Tehran

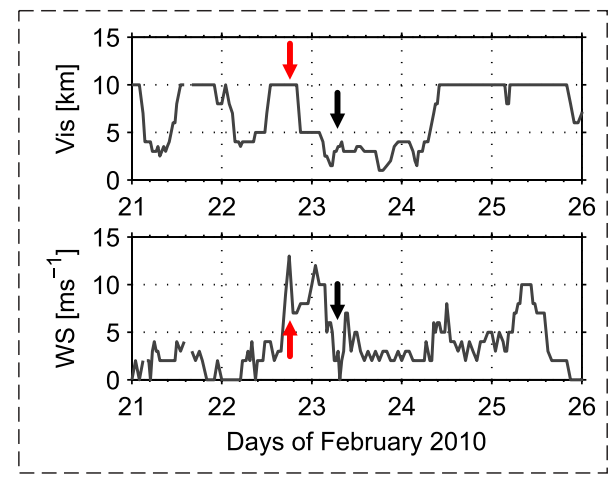

Figure 7. Hourly horizontal visibility (Vis, top) in $\mathrm{km}$ and wind speed (WS, bottom) in $\mathrm{m} \mathrm{s}^{-1}$ for the period of 21-26 February 2010 measured in Iran in (a) Tabriz, (b) Zanjan, (c) Qom and (d) Tehran (see Figure 1 for the location of the stations). Red arrows indicate the winter Shamal-related cold front crossing time at the stations (also see Table 1). Black arrows indicate the time of the sharp reduction of surface horizontal visibility associated with the downward mixing of dust in the PBL after sunset (see text for details).

cycle of the PBL, using the suite of remote sensing instruments and meteorological data at IASBS in Zanjan.

\subsection{Evolution of the Vertical Distribution of Dust in Zanjan}

[35] HYSPLIT-derived backward trajectories starting in Zanjan at 06:00 UTC on 23 February (Figure 8e) indicate that the air masses between 0.5 and $1.5 \mathrm{~km}$ have traveled over northern Iraq and Syria the previous day (22 February), while between 2 and $3 \mathrm{~km}$ the air masses have passed over Turkey.

[36] Focusing on the 21-23 February period, it can be seen that the value of the Angström exponent decreases with increasing AOD. The largest values $(\sim 1.5)$ are observed on 21 February, before the arrival of the cold front. At the time the cold front passes over Zanjan (midday on 22 February), the Angström exponent decreases to 0.5-0.6, thereby indicating the advection of bigger particles, likely dust [e.g., Holben et al., 1991]. Finally, at the time of the sharp reduction of visibility around 01:30 LT (05:00 UTC) on 23 February, the smallest Angström exponents are observed $(\sim-0.13 /-0.125)$. These values suggest the transport of even bigger particles in the air masses behind the cold front.

[37] Figure 9a shows the time-height series of lidar extinction coefficient profiles recorded at IASBS in Zanjan on 23 February 2010. High-value extinction coefficients are observed below $2 \mathrm{~km}$ agl from 04:30 LT (01:00 UTC), which correspond to the transport of dust over the Zanjan station. In the morning (04:30-08:30 LT, 01:00-05:00 UTC), the dust plume appears to be separated from the surface and to be overlying a cleaner layer as also seen in the extinction profile at 05:30 LT (02:00 UTC) (Figure 9c). The existence

Figure 8. (a) MODIS Deep Blue AOD at $550 \mathrm{~nm}$ on 23 February 2010. The location of Zanjan is marked with an asterisk, the daytime CALIPSO track is also overlaid as a solid green line; Dasht-e Kavir is displayed with dashed line. (b) CALIOPderived AOD along the CALIPSO track (solid red line) around 09:39 UTC on 23 February 2010. (c) Vertical cross section of CALIOP particle extinction coefficient (at $532 \mathrm{~nm}$ ) around 09:39 UTC on 23 February 2010. (d) HYSPLIT-derived $72 \mathrm{~h}$ backward trajectories ending in three locations over the Dasht-e Kavir desert near Qom $\left(34^{\circ} \mathrm{N} / 54^{\circ} \mathrm{E} ; 35^{\circ} \mathrm{N} / 52^{\circ} \mathrm{E} ; 34.5^{\circ} \mathrm{N} /\right.$ $53^{\circ} \mathrm{E}$ ) at 08:00 UTC on 23 February 2010 at three levels between 0.5 and $1.5 \mathrm{~km}$ agl. Dasht-e Kavir is displayed with dashed line (see section 2.4 and Figure 1 for details). (e) HYSPLIT-derived $72 \mathrm{~h}$ backward trajectories ending in three locations around Zanjan $\left(37.2^{\circ} \mathrm{N} / 48.0^{\circ} \mathrm{E} ; 36.2^{\circ} \mathrm{N} / 48.0^{\circ} \mathrm{E} ; 36.6^{\circ} \mathrm{N} / 49.2^{\circ} \mathrm{E}\right)$ at $06: 00 \mathrm{UTC}$ on 23 February 2010 at six levels between 0.5 and $3 \mathrm{~km}$ agl. 
of the clean air layer is further supported by the high horizontal visibility (in excess of $10 \mathrm{~km}$ ) reported by the Zanjan meteorological station observer until 06:30 LT (03:00 UTC) (Figure 9b). From 09:30 LT (06:00 UTC) onward, the Zanjan meteorological station observer reported low horizontal visibilities (1 km or lower) which are in agreement with the increase in aerosol extinction coefficient in the lower $500 \mathrm{~m}$ agl as seen in Figure 9a and at 12:10 LT (08:40 UTC) in Figure 9c.

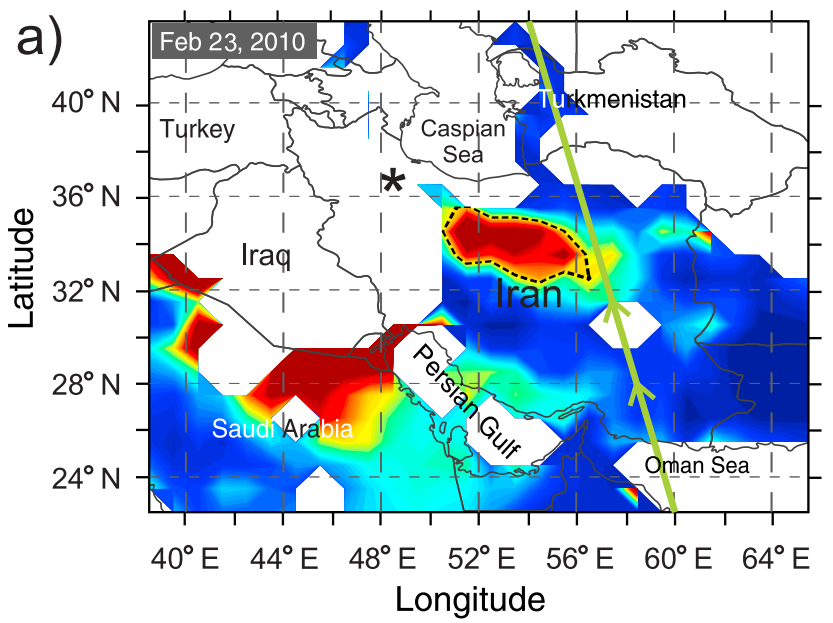

b)

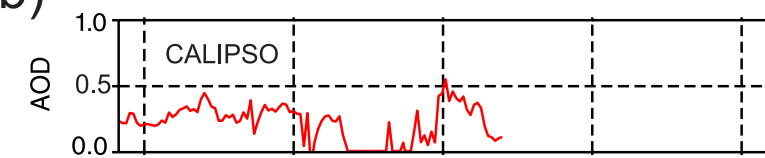

c)
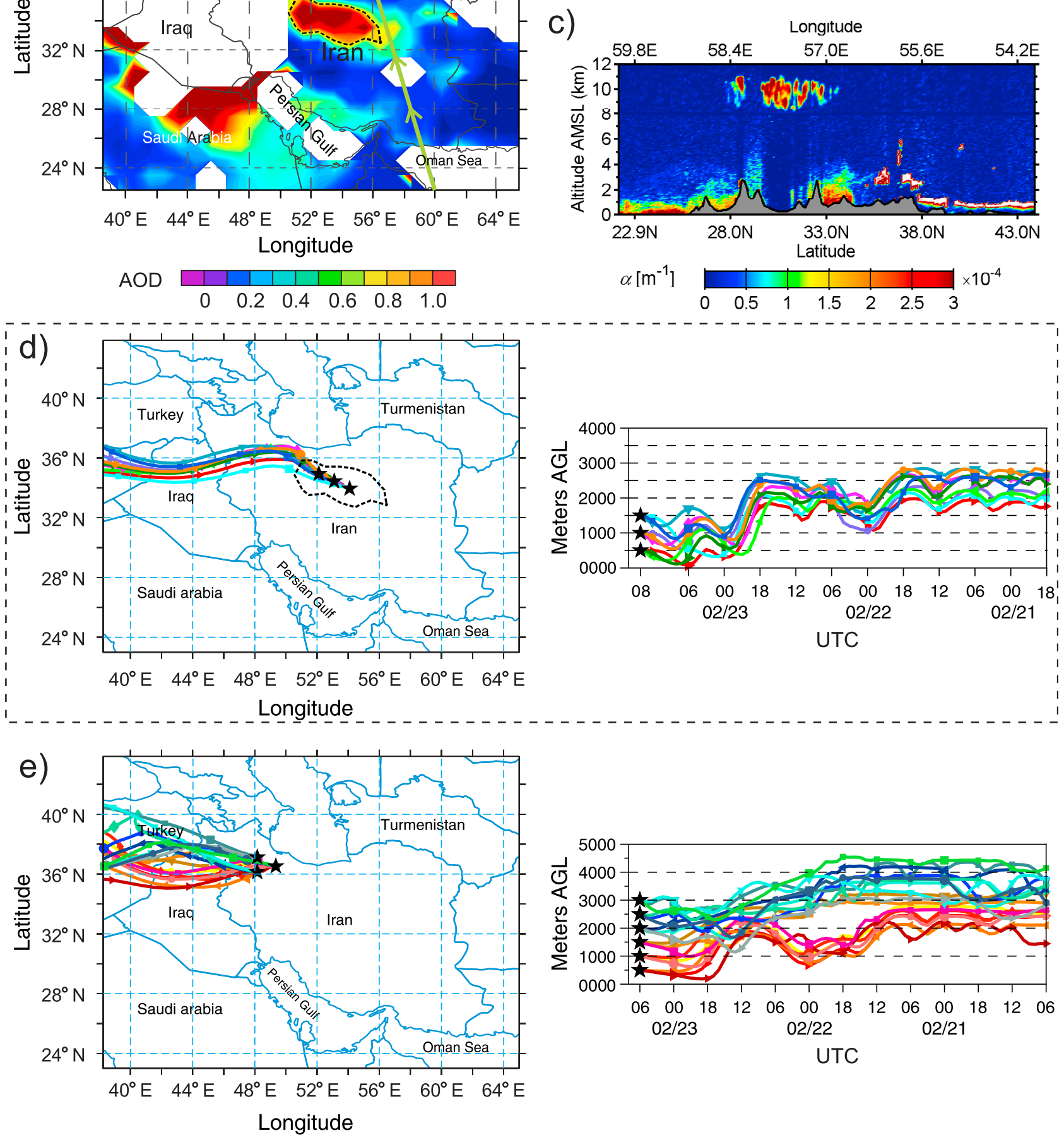

UTC

Figure 8 

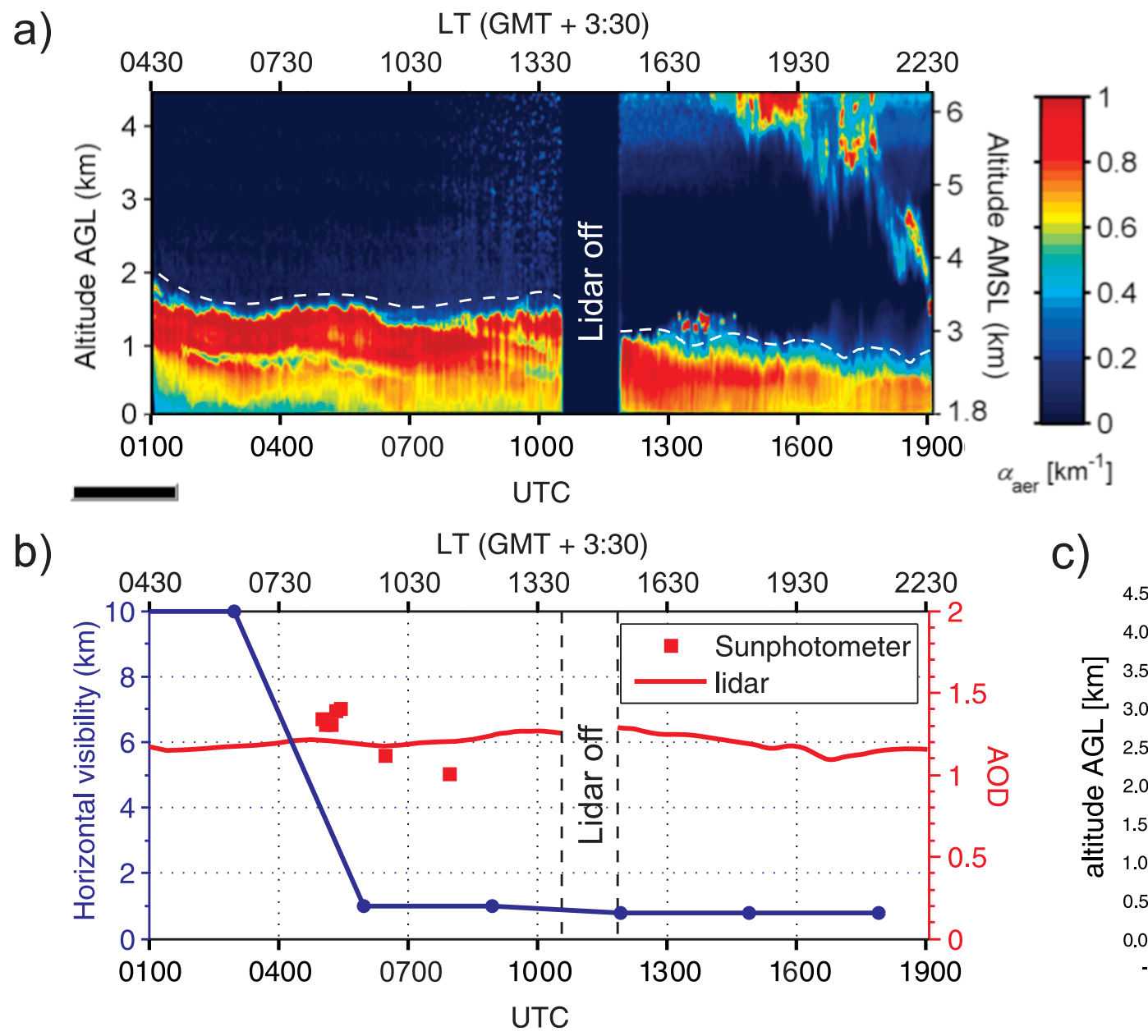

b)

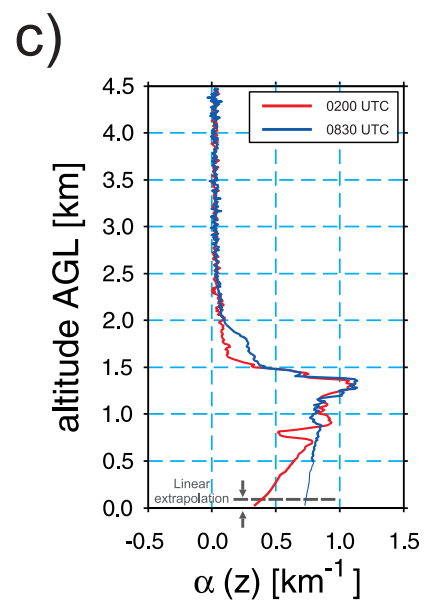

Figure 9. (a) Time-height series of lidar-derived extinction coefficient recorded in Zanjan (at $532 \mathrm{~nm}$ ) between 01:00 and 19:10 UTC on 23 February 2010. It is the entire available data set. The lidar was switched off between 10:30 and 12:00 UTC by the operator. Both UTC time (bottom axis) and local time (top axis) as well as both altitude above ground level (left axis) and above sea level (right axis) are indicated. (b) AOD measured by the Sun photometer in Zanjan between 05:00 UTC and 08:00 UTC at 670 nm (red squares). Because of cloud screening procedure of the level 2.0 processing by AERONET, the number of data points is limited in time. Lidar-derived AOD (red thick line) and horizontal visibility are reported by the Zanjan meteorological station ground observer between 22:30 UTC on 22 February 2010 and 15:30 UTC on 23 February 2010 (blue line). The lidar-derived AOD is obtained after integration of the aerosol extinction profile between the surface and the dashed line shown in Figure 9a. (c) Groundbased lidar-derived extinction coefficient recorded in Zanjan (at $532 \mathrm{~nm}$ ) at 02:00 UTC (solid red line) and 08:30 UTC (solid blue line).

[38] Associated with the dust plume, the Sun photometer at IASBS measured AODs in the 1 to 1.5 range between 08:00 and 11:00 LT (04:30 and 07:30 UTC) (Figure 9b). The lidar-derived AOD is also found to be relatively constant and around 1.2 until 14:30 LT (11:00 UTC) and to decrease afterward as the dust plume thinned out between 15:30 and 20:30 LT (12:00 and 17:00 UTC).

[39] Finally, the elevated dust layer appears to be descending before sunrise (occurring at 06:43 LT (03:13 UTC) on 23 February), as supported by the HYSPLIT backward trajectories, Figure 8e), because of strong subsidence prior to 09:30 LT (06:00 UTC) as confirmed by the ECMWF analyses above northwest Iran (not shown). On 23 February when the "new" convective BL develops after sunrise (around 06:30 LT, 03:00 UTC), it grows until its top reaches the elevated advecting dust layer (the PBL partly grows because of the entrainment process at its top). When the dust is entrained in the developing PBL, it is mixed in the vertical because of the strong turbulence in the PBL and high quantities of dust can reach the surface.

\section{Summary and Conclusion}

[40] Transport of desert dust over Iraq and northwest Iran associated with a wintertime case of Shamal winds has been studied using a suite of ground-based and spaceborne remote sensing platforms as well as modeling tools.

[41] During the 22-23 February 2010 case, dust emission regions were located in Syria/Iraq as in the summer cases 
reported by Abdi Vishkaee et al. [2011]. Emissions in Syria and Iraq occurred in response to strong northwesterly winter Shamal winds. Surface measurements over Iraq provided evidence that the visibility associated with dust lifting and transport by the Shamal winds was very low (less than $1 \mathrm{~km}$ ) and could last for 1 to 2 days. The sharp reduction in horizontal visibility observed over Iraq occurred shortly after the passage of the cold front (behind which the northwesterly Shamal was blowing) and was likely associated with the strong wind gust in the vicinity of the leading edge of the front.

[42] In this case, dust was transported toward the Zagros Mountains at low levels as in the September case detailed by Abdi Vishkaee et al. [2011]. Unlike what was observed over Iraq, low near-surface horizontal visibilities (less than $1 \mathrm{~km}$ ) over northwest Iran (e.g., Tabriz, Qom, Zanjan, and Tehran) were observed well after the passage of the cold front on 23 February 2010, generally in the hours following sunrise. Ground-based lidar measurements acquired in Zanjan have allowed new insights into this. They showed that in the wake of the front, dust from Syria/Iraq was transported in an elevated 1 to $1.5 \mathrm{~km}$ thick plume that was separated from the surface during the night/morning of 23 February. After sunrise, the entrainment process taking place at the top of the developing convective boundary layer led to mixing of the dust into the boundary layer and in turn to a sharp reduction of the horizontal visibility in Zanjan. Large AODs (larger than 1) were observed with the Sun photometer and the lidar until 13:30 UTC (17:00 LT) in Zanjan as well as with MODIS just east of Tehran around midday. The timing of the reduction of surface horizontal visibility in Tabriz, Qom, and Tehran (where there are no lidar data available), i.e., just after sunset, is consistent with the downward mixing of dust in the PBL as evidenced in Zanjan.

[43] The analysis of previously unavailable ground-based lidar data highlighted the importance of low-level transport of dust from both Iraq and Iran for air quality issues in a city located in northwest Iran, such as Zanjan. Furthermore, the analysis of the horizontal visibility data in other cities of Iraq and northwest Iran suggest that air quality can be adversely impacted during winter dust storms. For instance, the visibility in Tehran during 23 February was reduced to $\sim 2.5 \mathrm{~km}$ during most of the day, with minima below $200 \mathrm{~m}$ in some instances, in connection with the transport of dust at low levels, several hours after the synoptic cold front crosses Iran.

[44] In order to assess the impact of winter Shamal-related dust events on human health (respiratory and cardiovascular problems) and water resources and the damage on various sectors of the Iranian economy, additional study with adequate modeling tools is needed. This study sheds new light on the processes responsible for dust emission and transport over northwest Iran in connection with winter Shamal events.

[45] Acknowledgments. The authors gratefully acknowledge the NOAA Air Resources Laboratory (ARL) for the provision of the HYSPLIT transport and dispersion model and READY Web site used in this publication. The European Centre for Medium-Range Weather Forecasts (ECMWF) is acknowledged for making the meteorological analyses available from their data server. The CALIPSO data were obtained from the NASA Langley Research Center Atmospheric Science Data Center. MODIS deep blue aerosol optical depth used in this study were produced with the Giovanni online data system, developed and maintained by the NASA Goddard Earth Sciences (GES) Data and Information Services Center (DISC). The authors would like to acknowledge M. Hasanalizadeh, the director of Zanjan meteorological office, for preparing archived surface measurements; R. Moradhaseli for recording lidar data; and A. Bayat for useful discussions. Finally, the authors acknowledge the work of Earle Williams and two anonymous referees whose comment helped improved this paper.

\section{References}

Abdi Vishkaee, F., C. Flamant, J. Cuesta, P. Flamant, and H. Khalesifard (2011), Multi-platform observations of dust vertical distribution during transport over northwest Iran in the summertime, J. Geophys. Res., 116, D05206, doi:10.1029/2010JD014573.

Adlerman, E. J., K. K. Droegemeier, and R. Davies-Jones (1999), A numerical simulation of cyclic mesocyclogenesis, J. Atmos. Sci., 56, 2045-2069, doi:10.1175/1520-0469

Ali, A. H. (1994), Wind regime of the Arabian Gulf, in The Gulf War and the Environment, edited by F. El-Baz and R. M. Makharita, pp. 31-48, Gordon and Breach, New York.

Barrie, L., and S. Nickovic (2010), Aerosol impacts on health and environment: Research, monitoring and prediction, paper presented at GEO Health and Environment COP Workshop, CNES, Paris, 27-28 July.

Bayat, A., A. Masoumi, and H. R. Khalesifard (2011), Retrieval of atmospheric optical parameters from ground-based Sun-photometer measurements for Zanjan area, Atmos. Meas. Tech., 4, 857-863, doi:10.5194/ amt-4-857-2011.

Cuesta, J., et al. (2008), Multiplatform observations of the seasonal evolution of the Saharan atmospheric boundary layer in Tamanrasset, Algeria, in the framework of the African Monsoon Multidisciplinary Analysis field campaign conducted in 2006, J. Geophys. Res., 113, D00C07, doi:10.1029/2007JD009417.

Cuesta, J., J. H. Marsham, D. J. Parker, and C. Flamant (2009), Dynamical mechanisms controlling the vertical redistribution of dust and the thermodynamic structure of the West Saharan atmospheric boundary layer during summer, Atmos. Sci.Lett., 10(1), 34-42.

Dee, D. P., et al. (2011), The ERA-Interim reanalysis: configuration and performance of the data assimilation system, Q.J. R. Meteorol. Soc., 137, 553-597, doi:10.1002/qj.828.

Draxler, R. R., and G. D. Rolph (2003), HYSPLIT (HYbrid Single-Particle Lagrangian Integrated Trajectory) model access via NOAA ARL READY Website (http://www.arl.noaa.gov/ready/hysplit4.html), NOAA Air Resour. Lab., Silver Spring, Md.

Dubovik, O., A. Smirnov, B. N. Holben, M. D. King, Y. J. Kaufman, T. F. Eck, and I. Slutsker (2000), Accuracy assessments of aerosol optical properties retrieved from AErosol RObotic NETwork (AERONET) sun and sky radiance measurements, J.Geophys. Res., 105, 9791-9806.

Emery, K. O. (1956), Sediments and water of the Persian Gulf, AAPG Bull., $40,2354-2383$.

Fernald, F. G. (1984), Analysis of atmospheric lidar observations: Some comments, Appl. Opt., 23(5), 652-653.

Fernald, F. G., B. M. Herman, and J. A. Reagan (1972), Determination of aerosol height distributions by lidar, J. Atmos. Meteorol., 11(3), 482-489.

Goff, R. C. (1976), Vertical structure of thunderstorm outflows, Mon. Weather Rev., 104, 1429-1440.

Holben, B. N., T. F. Eck, and R. S. Fraser (1991), Temporal and spatial variability of aerosol optical depth in the Sahel region in relation to vegetation remote sensing, Int. J. Remote Sens., 12(6), 1147-1163.

Hsu, N. C., S.-C. Tsay, M. D. King, and J. R. Herman (2004), Aerosol properties over bright-reflecting source regions, IEEE Trans. Geosci. Remote Sens., 42(3), 557-569.

Hubert, W. E., D. R. Morford, A. N. Hull, and R. E. Englebretson (1983), Forecasters handbook for the Middle East/Arabian sea, Rep. CR 83-06, Nav. Environ. Predict. Res. Facil., Monterey, Calif.

Kaufman, Y., D. Tanré, J.-F. Léon, and J. Pelon (2003), Retrievals of profiles of fine and coarse aerosols using lidar and radiometric space measurements, IEEE Trans. Geosci. Remote Sens., 41(8), 1743-1754, doi:10.1109/TGRS.2003.814138.

Khalesifard, H. R., F. Abdi Vishkaee, and P. H. Flamant (2005), Cloud track wind using synergism of backscatter lidar and sky digital picture, Proc. SPIE, 5979, 59790C, doi:10.1117/12.629436.

Kutiel, H., and H. Furman (2003), Dust storms in the Middle East: Sources of origin and their temporal characteristics, Indoor Built Environ., 12(6), 419-426, doi:10.1177/1420326X03037110.

Mahowald, N. M., J. A. Ballentine, J. Feddema, and N. Ramankutty (2007), Global trends in visibility: Implications for dust sources, Atmos. Chem. Phys., 7, 3309-3339.

Messager, C., D. J. Parker, O. Reitebuch, A. Agusti-Panareda, C. M. Taylor, and J. Cuesta (2010), Structure and dynamics of the Saharan atmospheric boundary layer during the West African monsoon onset: Observations and analyses from the research flights of 14 and 17 July, Q. J. R. Meteorol. Soc., 136, 107-124, doi:10.1002/gj.469. 
Middleton, N. (1986a), Dust storms in the Middle East, J. Arid Environ., 10, 83-96.

Middleton, N. (1986b), A geography of dust storms in Southwest Asia, J. Clim., 6, 183-196.

Miller, S. D., A. P. Kuciauskas, M. Liu, Q. Ji, J. S. Reid, D. W. Breed, A. L. Walker, and A. A. Mandoos (2008), Haboob dust storms of the Southern Arabian Penninsula, J. Geophys. Res., 113, D01202, doi:10.1029/ 2007JD008550.

Miri, A., H. Ahmadi, A. Ghanbar, and A. Moghaddamnia (2007), Dust storms impacts on air pollution and public health under hot and dry climate, Int. J. Energy Environ., 2, 101-105.

Perrone, T. J. (1979), Winter Shamal in the Persian Gulf, Tech. Rep. TR 79-06, 168 pp., Nav. Environ. Predict. Res. Facil., Monterey, Calif.

Prospero, J. M., P. Ginoux, O. Torres, S. E. Nicholson, and T. E. Gill (2002), Environmental characterization of global sources of atmospheric soil dust identified with the NIMBUS 7 Total ozone mapping spectrometer (TOMS) absorbing aerosol product, Rev. Geophys., 40(1), 1002 doi:10.1029/2000RG000095.

Pye, K. (1987), Aeolian Dust and Dust Deposit, 335 pp., Academic, San Diego, Calif.

Rao, P. G., M. Al-Sulaiti, and A. H. Al-Mulla (2001), Winter Shamals in Qatar, Arabian Gulf, Weather, 56, 444-451.

Reynolds, R. M. (1993), Physical oceanography of the Gulf, Strait of Hormuz, and the Gulf of Oman (Results from the Mt. Mitchell expedition), Mar. Pollut. Bull., 27, 35-59.

Rolph, G. D. (2003), Real-time Environmental Applications and Display sYstem (READY), report, NOAA Air Resour. Lab., Silver Spring, Md. (Available at http://ready.arl.noaa.gov/HYSPLIT_traj.php.)

Safar, M. I. (1980), Dust and duststorms in Kuwait, report, 137 pp., Dir. Gen. of Civ. Aviation, Meteorol. Dep., Climatol. Sect., Kuwait City.
Salustro, C., C. Hsu, and M. J. Jeong (2009), Validation of MODIS-Aqua deep blue aerosol products over bright surfaces, paper presented at 8th Annual AeroCom Workshop, GFDL, Princeton, N. J., 5-7 Oct.

Salustro, C., C. Hsu, and M. J. Jeong (2010), MODIS ddeep blue: Validation of recent products and future plans, paper presented at MODIS/ VIIRS Science Team Meeting, NASA, Washington, D. C., 26-28 Jan.

Simpson, J. E. (1987), Gravity Currents: In the Environment and the Laboratory, John Wiley, New York.

Tesche, M., et al. (2009), Vertical profiling of Saharan dust with Raman lidars and airborne HSRL in southern Morocco during SAMUM, Tellus, Ser. B, 61(1), 144-164.

Wilkerson, W. D. (1991), Dust and sand forecasting in Iraq and adjoining countries, Tech. Note AWS/TN-91/001, 63 pp., Air Weather Serv., Scott AFB, Ill.

Winker, D. M., W. H. Hunt, and M. J. McGill (2007), Initial performance assessment of CALIOP, Geophys. Res. Lett., 34, L19803, doi:10.1029/ 2007 GL030135.

F. Abdi Vishkaee and P. Flamant, Laboratoire de Météorologie Dynamique, CNRS, Ecole Polytechnique, F-91128 Palaiseau, France. (farhadeabdi@gmail.com)

J. Cuesta, Laboratoire Inter-Universitaire des Systèmes Atmosphèriques, Université Paris Est Créteil, 61, Avenue du Général de Gaulle, F-94010 Créteil CEDEX, France.

C. Flamant, Laboratoire Atmosphères, Milieux, Observations Spatiales, CNRS and Université Pierre et Marie Curie, Boite 102, 4, place Jussieu, F-75252 Paris, France.

H. R. Khalesifard, Institute for Advanced Studies in Basic Sciences, Zanjan 4513879368, Iran.

L. Oolman, Department of Atmospheric Science, University of Wyoming, PO Box 3038, 16th and Gibbon, Laramie, WY 82071, USA. 